\title{
Pưvodní sdělení | Original article/Research Proteomic analysis of the plasma samples of patients with stable angina pectoris
}

\author{
Martin Malýa, Pavel Májek ${ }^{\mathbf{b}}$, Zuzana Reicheltováb, Jiří Suttnarb, \\ Roman Kotlín ${ }^{b}$, Petr Hájek ${ }^{a}$, Milan Oravec $^{a}$, Jan E. Dyr ${ }^{b}$, Josef Veselka \\ ${ }^{a}$ Kardiologická klinika, 2. lékařská fakulta Univerzity Karlovy a Fakultní nemocnice Motol, Praha, Česká republika \\ b Ústav hematologie a krevní transfuze, Praha, Česká republika
}

INFORMACE O ČLÁNKU

Historie článku:

Došel do redakce: 17. 12. 2011

Přepracován: 14. 1. 2012

Prijat: 20. 1. 2012

Keywords:

Angina pectoris

Mass spectrometry

Proteomic analysis
Klíčová slova:

Angina pectoris

Hmotnostní spektrometrie

Proteomické vyšetření

\begin{abstract}
Objective: In this study, the results of the proteomic analysis of plasma samples of stable angina patients are presented.

Background: Plasma samples from 44 patients were analysed in two groups: A) a control group of 22 patients without significant coronary artery disease and B) 22 patients admitted with stable angina pectoris. Methods: During coronary angiography, plasma samples were collected and further analysed using two-dimensional gel electrophoresis, image analysis and mass spectrometry.

Results: Five spots were found with significantly increased or decreased normalised volumes resulting from either a change in the amount of protein or changes in posttranslational modifications. Spots containing serum amyloid A protein and fibrinogen gamma chains displayed increased normalised volumes, and spots containing apoliprotein A-1 and pigment epithelium-derived factor showed decreased normalised volumes. Conclusions: Almost identical proteomic profiles of the stable angina pectoris group compared with the control group corresponded well with clinical results comparing stable patients with the general population.
\end{abstract}

\section{SOUHRN}

Cíl: Práce prezentuje výsledky proteomického vyšetření plazmy u pacientů se stabilní anginou pectoris. Soubor a metodika: Celkem byly vyšetřeny vzorky plazmy od 44 nemocných rozdělených do dvou skupin: A) kontrolní skupina 22 nemocných bez významné koronární nemoci a B) 22 nemocných se stabilní anginou pectoris. Vzorky plazmy byly odebrány během koronární angiografie a dále analyzovány pomocí dvojrozměrné elektroforézy, analýzy snímků a hmotnostní spektrometrie.

Výsledky: Celkem v pěti spotech jsme nalezli rozdíly v normalizovaných objemech, kdy změna normalizovaného objemu je dána bud' změněným množstvím proteinu, nebo jeho posttranslačními modifikacemi. Zvýšení normalizovaných objemů se nacházelo ve spotech obsahujících sérový amyloid $A$ a gama řetězce fibrinogenu. Naopak snižené normalizované objemy vykazovaly spoty obsahující apolipoprotein A-1 a pigment epithelium-derived factor.

Závěr: Skupina se stabilní anginou pectoris vykazovala téměř identický proteomický profil jako kontrolní skupina, což dobře koresponduje s klinickou zkušeností prakticky stejného klinického průběhu u stabilních pacientů v porovnání s obecnou populací.

(c) 2012, CKKS. Published by Elsevier Urban and Partner Sp. z.o.o. All rights reserved.

Adresa: MUDr. Martin Malý, Ph.D., Kardiologická klinika, 2. lékařská fakulta Univerzity Karlovy a Fakultní nemocnice Motol, 


\section{Introduction}

The development of genetic research to rapidly move from bench to bedside is one of the most challenging fields for clinically applied research. Molecular profiling technologies to assess the occurrence, appearance and amounts of DNA, RNA, protein and metabolites are the foundation for the "omics" disciplines (genomics, proteomics and metabolomics). These disciplines provide the opportunity to potentially strengthen the concept of "personalised medicine". Genomics is utilising methods to identify genes and their polymorphisms to compare the results with phenotypes and vice versa. Different types of genetic studies are used for this purpose [1,2]. Next, proteomic and metabolomic disciplines analyse the final results of genes - metabolites, proteins and their posttranslational modifications. Progress in the search for new therapeutic tools and potentially new biomarkers in atherosclerosis has moved forward due to analysis of genes, results of their expression and identification of proteins using proteomic analysis [3]. We are presenting the results of proteomic analysis of plasma samples from stable angina pectoris patients.

\section{Patients and methods}

Plasma samples were collected from 44 patients in two subgroups: A) 22 patients without significant coronary artery disease (controls) and B) 22 patients with stable angina pectoris (SAP) and significant coronary artery disease according to angiography. The characteristics of the study groups are summarised in Table 1. The reasons for coronary angiography of the controls are summarised in Table 2.
Table 2 - Final diagnosis in the control group.

\begin{tabular}{lr} 
& $\mathrm{N}$ \\
\hline Atypical chest pain & 18 \\
Cardiomyopathy & 2 \\
Valve disease & 2 \\
\hline
\end{tabular}

Table 3 - Classification and angiographic results of the stable angina subgroup.

\begin{tabular}{lr} 
& $\mathrm{N}(\%)$ \\
\hline CCS 1 & $4(18)$ \\
CCS 2 & $12(55)$ \\
CCS 3 & $6(27)$ \\
1 VD & $6(27)$ \\
2 VD & $9(41)$ \\
3 VD & $7(32)$ \\
\hline
\end{tabular}

CCS - severity of angina according to the Canadian Cardiovascular Society classification; VD - number of vessel diseased.

Subgroup $A$ is a heterogeneous population with the common characteristic of the absence of significant coronary artery disease during coronary angiography. Subgroup B consists of the patients undergoing angiography due to SAP. 13 patients had the history of typical chest pain during exertion and established ischemic heart disease with known coronary artery disease, and 9 patients had history of typical chest pain and newly diagnosed significant coronary artery disease on the coronary angiography. The classification of the SAP and the angiographic results are summarised in Table 3 . All of the patients

\section{Table 1 - Demographics and list of medication on admission.}

\begin{tabular}{|c|c|c|c|}
\hline & A (control) & $\mathrm{B}(\mathrm{SAP})$ & $p$ \\
\hline Patients, $\mathrm{n}$ & 22 & 22 & \\
\hline Men/Woman, n (\%) & $9(41) / 13(59)$ & $16(73) / 6(27)$ & 0.0666 \\
\hline Age, years $\pm S D$ & $64.0 \pm 12.6$ & $64.7 \pm 9.3$ & 0.8601 \\
\hline \multicolumn{4}{|l|}{ Risk factors } \\
\hline Hypertension, n (\%) & $11(50)$ & $21(95)$ & 0.0015 \\
\hline Smoking, $\mathrm{n}(\%)$ & $3(14)$ & $7(32)$ & 0.2806 \\
\hline Dyslipidaemia, n (\%) & $13(59)$ & $18(82)$ & 0.1854 \\
\hline Diabetes, n (\%) & $6(27)$ & $9(41)$ & 0.5256 \\
\hline \multicolumn{4}{|c|}{ Medication on admission } \\
\hline Beta blockers, n (\%) & $6(27)$ & $14(64)$ & 0.0329 \\
\hline Aspirin, $n(\%)$ & $9(41)$ & $16(73)$ & 0.0666 \\
\hline ADP blockers, n (\%) & $2(9)$ & $5(23)$ & 0.4121 \\
\hline Statins, n (\%) & $12(55)$ & $18(82)$ & 0.5365 \\
\hline Nitrates, n (\%) & $1(5)$ & $5(23)$ & 0.1853 \\
\hline ACE inhibitors, $n(\%)$ & $5(23)$ & $14(64)$ & 0.0139 \\
\hline$A R B, n(\%)$ & $2(9)$ & $3(14)$ & 1.0000 \\
\hline Ca blockers, n (\%) & $4(18)$ & $5(23)$ & 1.0000 \\
\hline Coumadin, n (\%) & $2(9)$ & $2(9)$ & 1.0000 \\
\hline
\end{tabular}

ACE - angiotensin converting enzyme; ADP - adenosine diphosphate; ARB - angiotensin receptor blockers; Ca - calcium; dyslipidaemia (statin use or increased cholesterol levels); SD - standard deviation. 
agreed to participation in the study and signed a consent approved by the Ethics Committee of the University Hospital Motol.

\section{1) Blood sampling}

Blood was collected by venipuncture into tubes coated with EDTA. Plasma was obtained by centrifugation ( $15 \mathrm{~min}$, $3,000 \times \mathrm{g}$ ) of blood samples. The supernatant was centrifuged once more under the same conditions. Subsequently, the obtained (clear) plasma was transferred to polypropylene Eppendorf tubes and stored at $-70^{\circ} \mathrm{C}$ until used.

\section{2) Plasma depletion}

Plasma depletion is based on the removal of abundant proteins, which constitute more than $90 \%$ of protein mass in plasma. The depletion is necessary to uncover small proteins with low plasma concentrations. In our study, six proteins were depleted (albumin, IgG, $\alpha 1$-antitrypsin, IgA, transferrin and haptoglobin).

Plasma samples were centrifuged $(5 \mathrm{~min}, 12,000 \times \mathrm{g})$, diluted $1: 4$ in depletion buffer (Agilent, CA, USA) and filtered using $0.22 \mu \mathrm{m}$ Spin filters (Agilent Technologies, USA) for 1 minute by centrifugation at $12,000 \times \mathrm{g}$. MARS Hu-6 $4.6 \times 100 \mathrm{~mm}$ columns (Agilent Technologies, CA, USA) were used to remove the six most abundant proteins (albumin, IgG, $\alpha 1$-antitrypsin, IgA, transferrin and haptoglobin). Spin Concentrators 5K MWCO (Agilent Technologies, CA, USA) were used to desalinate and concentrate the samples $\left(3,000 \times \mathrm{g}, 20^{\circ} \mathrm{C}\right)$. MilliQ water $(4 \mathrm{ml})$ was added to concentrated samples, and the desalinatingconcentrating step was repeated three times. Finally, desalinated and concentrated samples were vacuum dried, frozen rapidly and stored at $-70^{\circ} \mathrm{C}$.

\section{3) Two-dimensional electrophoresis (2D SDS-PAGE)}

Two-dimensional electrophoresis was performed as described previously [4]. Briefly, the samples were resuspended and centrifuged at $37,500 \times \mathrm{g}$ at $20^{\circ} \mathrm{C}$ for an hour. Following IEF, strips were equilibrated for $20 \mathrm{~min}$ in DTT followed by equilibration in iodoacetamide. Proteins were separated in the second dimension on SDS-PAGE. Following electrophoresis, the gels were stained with colloidal Coomassie blue stain $(17 \% \mathrm{w} / \mathrm{v}$ ammonium sulfate, $1.8 \% \mathrm{H}_{3} \mathrm{PO}_{4}, 35 \% \mathrm{v} / \mathrm{v}$ methanol and $0.12 \%$ Serva Blue $\mathrm{G}$ ) for at least 24 hours and destained with $1 \%$ acetic acid.

\section{4) Image analysis}

Scanned images (16-bit grayscale) were processed with Progenesis SameSpots software (Nonlinear Dynamics, UK). Both manual and automatic alignments were used to align the images. Normalised volumes of the spots, instead of spot intensity, were used in the statistical analysis, and only spots that fulfilled statistical criteria (ANOVA $p<0.05$ and fold $\geq 1.5$ ) were accepted for protein identification. The fold change is a value related to the average amount of all proteins in the spot calculated as a ratio normalised to the control. The fold change value shown in the spot list is calculated from the mean normalised volumes of respective spots in sample and control gels.

\section{5) In-gel digest}

Selected spots were excised from the gel and destained in a $1: 1$ ratio of $100 \mathrm{mM} \mathrm{NH}_{4} \mathrm{HCO}_{3}$ and acetonitrile. Destained gel pieces were dehydrated with acetonitrile, rehydrated with $100 \mathrm{mM} \mathrm{NH}_{4} \mathrm{HCO}_{3}$ and then dehydrated with acetonitrile once again. Finally, vacuum dried gel pieces were rehydrated in trypsin solution $(12.5 \mathrm{ng} / \mu \mathrm{l}$ of trypsin in $25 \mathrm{mM} \mathrm{NH}_{4} \mathrm{HCO}_{3}$ ), and then trypsin digestion was performed at $37{ }^{\circ} \mathrm{C}$ for 16 hours. Next, a solution of $50 \%$ acetonitrile $/ 0.1 \%$ formic acid was added to the gel pieces, and peptides were extracted by agitation for $15 \mathrm{~min}$. The supernatant was recovered, and the extraction step was repeated once again. The supernatants were pooled, dried and dissolved in $2 \%$ acetonitrile/0.1\% formic acid.

\section{6) Liquid chromatography (LC) \\ and mass spectrometric analysis (MS)}

An ion-trap mass spectrometer (MS HCT ultra [Bruker Daltonik, Germany] with nanoelectrospray ionisation coupled to the nanoLC system UltiMate 3,000 [Dionex Corporation, CA, USA]) was used to perform mass spectrometric analyses. Tryptic peptides were desalted on a $300 \mu \mathrm{m}$ ID/5 mm-length C18 PepMap 100 precolumn (LC Packings, CA, USA) and separated on a $75 \mu \mathrm{m} I D / 15 \mathrm{~cm}-$ length C18 PepMap 100 analytical column (LC Packings, CA, USA). A gradient of acetonitrile was used to elute peptides ( $0 \%$ to $20 \%$ B in $2 \mathrm{~min}, 20 \%$ to $50 \%$ B in $15 \mathrm{~min}$; mobile phase A: $2 \%$ ACN $/ 0.1 \%$ formic acid, mobile phase B: $80 \%$ ACN $/ 0.1 \%$ formic acid) at a flow rate of $300 \mathrm{nl} / \mathrm{min}$. The nanoLC system was connected to MS using a PicoTip needle (New Objective, MA, USA) with an applied voltage of $1,500 \mathrm{~V}$. The flow of the dry gas was $10 \mathrm{l} / \mathrm{min}$ with a dry temperature of $160{ }^{\circ} \mathrm{C}$. The "Standard Enhanced" positive scan mode for collision induced dissociation (CID) data acquisition was used. The scan ranges were 300 to $1,500 \mathrm{~m} / \mathrm{z}$ and 100 to $2,500 \mathrm{~m} / \mathrm{z}$ for MS and MS(2), respectively. Three precursor ions were selected during one autoMs(2) cycle, and active exclusion (0.35 min, singly charged ions) was used. EsquireControl v6.2 software was used for data acquisition. DataAnalysis v4.0 was used for data processing, and BioTools v3.2 (all software above, Bruker Daltonik, Germany) together with MASCOT (Matrix Science, UK) were used for database searching (SWISSPROT 57.0). The following database search parameters were utilised: taxonomy was restricted to Homo sapiens, carbamidomethyl (C) was selected as a fixed modification and oxidation $(\mathrm{M})$ as a variable modification, the number of missed cleavages was restricted to 1 , mass was monoisotopic and the mass tolerance was $0.1 \%$ for MS and 0.5 Da for MS/MS.

\section{Results}

Altogether, 44 2D SDS-PAGE gels were processed throughout the experiment. Scanned gel images were divided into two individual subgroups: A) controls (22 gels) and B) stable angina pectoris (22 gels). Progenesis SameSpots software was utilised to process the image analysis. Using both manual and automatic image alignment, applying 


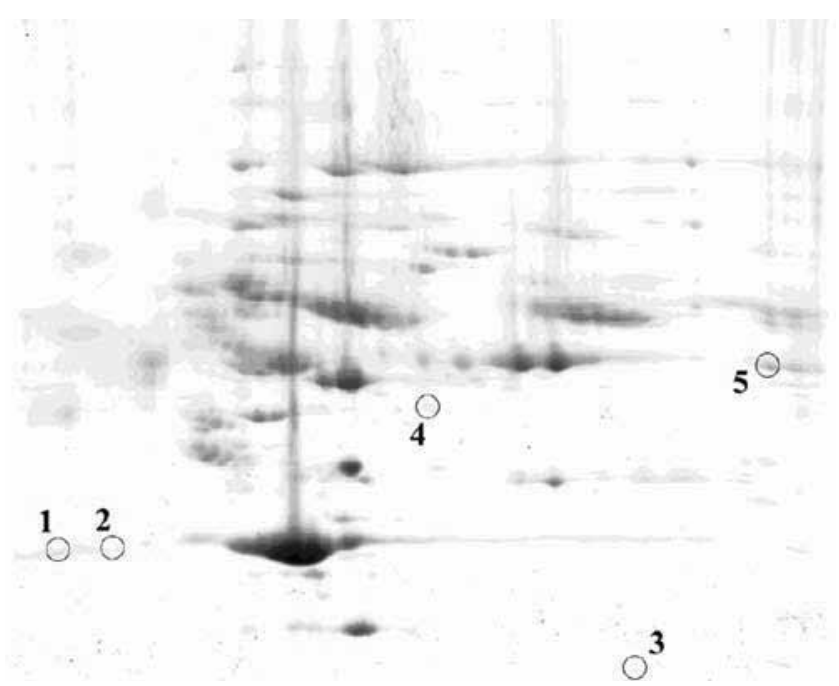

Fig. 1 Five different spots on 2D SDS-PAGE

pre-filtering (edge and area exclusion, minimal spot area or normalised volume) and specific criteria (ANOVA $p<0.05$, minimum fold change of 1.5 ), five spots were detected that significantly differed in their normalised volumes (Fig. 1). Four proteins in these five spots were successfully identified by nanoscale liquid chromatography/tandem mass spectrometry (nanoLC-MS/MS). At least two protein-unique peptides (fulfilling a minimal MASCOT score) were necessary for the identification of a protein. The list of spots, including protein identification with ANOVA $p$-value, fold difference, sequence coverage protein and accession number (SWISS-PROT 57.0), are summarised in Table 4.

Increased or decreased normalised volumes of protein mass are due to changes in amount of protein or due to posttranslational modifications. Compared to controls, the stable angina pectoris subgroup showed increased normalised volumes of two spots containing the serum amyloid $A$ and fibrinogen chains. Decreased normalised volumes were identified in three spots containing apoliprotein A-1 and pigment epithelium-derived factor (PEDF).

\section{Discussion}

Humans have 30,000 to 40,000 genes, which is only approximately twice the number of less complex organisms such as worms. However, a single gene might yield different proteins due to alternative splicing of transcripts and protein post-translational changes. Thus, although the genome is stable and gives information about the potential of an organism, the proteome is dynamic and reflects the biological processes that are taking place in that organism. Both approaches are complementary and, along with transcriptomics and metabolomics (which study the transcripts and the metabolites, respectively), integrate the so-called "omic" sciences [6].

Proteomic analysis can utilise almost any tissue. The analysis of the atherosclerotic plaques has identified osteopontin as a potential biomarker of poor prognosis. During three years of follow up, it was confirmed that a high expression of osteopontin was associated with a higher incidence of cardiovascular events [7].

Proteomic analysis of whole blood is methodologically easier. The proteome of the blood cells or plasma can be investigated. The analysis of the blood cells is more difficult because of the necessity of the isolation of the cells and extraction of the proteins. These investigations are also difficult because of the critical time delay (no more than four hours) to process samples. Plasma samples differ in that frozen samples can be stored for a long time.

During the analysis of circulating monocytes sampled from patients with acute coronary syndrome without ST elevations, 17 proteins with altered expression were altogether identified when compared with patients with stable angina pectoris. There were decreased antiatherogenic proteins such as paraoxonase or HSP 70 and antiinflammatory proteins such as protein disulfide isomerase. Increased expression was associated with cathepsin D and enolasis I [8].

Proteomic analysis faces many limitations. As mentioned in the methods section, six proteins (albumin, IgG, $\alpha 1$-antitrypsin, IgA, transferrin and haptoglobin) represent more than $90 \%$ of the protein plasma mass. The depletion process separates these proteins as well as proteins that are associated, mainly to albumin. However, without this depletion, further analysis is impossible. Another limitation is the sensitivity of the method. Using a proteomic approach in plasma, only approximately 3,000 genes are now recognised $[9,10]$, much less than the hypothetically anticipated 900,000 .

Proteomic analysis of patients with ischemic stroke confirmed high levels of haptoglobin and serum amyloid $A$ in the subgroup of patients with atherothrombotic events in comparison with embolic events [11]. In pa-

Table 4 - List of identified proteins.

\begin{tabular}{llrrr} 
AN & Identification & $p$ & Fold & SC (\%) \\
\hline P02647 & Apolipoprotein A-1 & 0.0035 & -1.6 & 50 \\
P02647 & Apolipoprotein A-1 & 0.0134 & -1.8 & 47 \\
P02735 & Serum amyloid A protein & 0.0304 & 1.9 & 36 \\
P36955 & Pigment epithelium-derived factor & 0.0099 & -1.5 & 36 \\
P02679 & Fibrinogen gamma chain & 0.0001 & 1.6 & 27 \\
\hline
\end{tabular}

The list of spots including protein identification with ANOVA p-value, fold difference (when compared with the control group), SC: sequence coverage of protein (\%). 
tients with acute coronary syndrome, studies show decreased levels of different isoforms of $\alpha 1$-antitrypsin or apolipoprotein A-1 and increased levels of fibrinogen chains and heavy chain gammaglobulins [12].

In our research, we compared two subgroups of patients: (1) with stable angina pectoris and (2) without documented significant coronary artery disease. A subgroup of patients without coronary artery disease served as controls. The results of proteomic analysis found only very discrete changes in the spectrum of proteins, which correlates well with clinical observations of small differences in patients with stable ischemic heart disease compared to the general population. The level of the disease documented by severity of angina seems not to influence the spectrum of molecules because increasing angina is here associated with the severity and extension of the atherosclerotic lesions, more then with superimposed thrombosis, which causes the acute coronary syndrome and where molecular spectrum will be due to thrombotic process different [12]. In the plasma of patients with stable angina pectoris, our results show increased levels of serum amyloid $A$ and gamma chains of fibrinogen. Decreased levels of apolipoprotein A-1 and pigment epithelium-derived factor (PEDF) were also found.

Serum amyloid A protein is a member of the family of inflammatory proteins. $C$ reactive protein belongs to the same family and is currently widely used as an indicator for increased risk of cardiovascular events $[13,14]$. Serum amyloid A protein was reported to have a more rapid response and different kinetics. Its addition to the $\mathrm{C}$ reactive protein level indicators increases the predictive value for the risk of death, myocardial (re)infarction and the need for target-vessel revascularisation in 30 days, compared with $C$ reactive protein levels alone $[15,16]$. Increased levels of $C$ reactive protein and serum amyloid A protein were the independent predictors of poor prognosis in severe unstable angina patients at admission [17].

Besides its role in inflammation, fibrinogen plays an important role in the coagulation cascade, and it is established that increased $C$ reactive protein and fibrinogen levels are predictors of poor long term prognosis $[18,19]$. Both of these findings correlate well with current established pathophysiology of atherosclerosis.

The role of apolipoprotein A-1 has been widely investigated. Apolipoprotein A-1 is a major apoliprotein of $\mathrm{HDL}$ cholesterol and is protective against atherosclerosis through several mechanisms including the ability to mediate reverse cholesterol transfer [20]. In the setting of coronary artery disease, dysfunctional HDL cholesterol has been found to be caused by oxidative damage [21]. The decreased presence of apoliprotein A-1 found in the subgroup of acute coronary syndrome patients correlates well with the lipid theory of atherosclerosis.

PEDF is involved in pathogenesis of diabetic proliferative retinopathy. Because of the fact that atherosclerosis is a proliferative and inflammatory disease, and PEDF blocks reactive oxygen radicals, one can assume the important role also in the atherosclerosis [22].

Our results suggest that the subgroup without clinical manifestation of atherosclerosis and the subgroup with chronic ischemic heart disease are, from the point of pro- teomic view, identical. This corresponds with the view of atherosclerosis as a systemic disease where one can suppose some degree of atherosclerotic disease by the age of 50 in persons exposed to risk factors. Their clinical characteristics correspond only with the severity of the disease and not with presence or absence of atherosclerosis.

In this study, the small numbers of patients has so far been the limitation of all proteomic studies due to methodological complexity and expense.

\section{Conclusions}

Our results show the availability and utility of proteomic analysis as a method for prognosis and its shift from bench to bedside, which brings new insight into both the pathophysiology and clinical manifestation of atherosclerosis.

\section{Acknowledgments}

This study was supported by Grants NS10633-3/2009, MZOFNM2005 and MZ 02373601 from the Ministry of Health, Czech Republic; by Grant KAN200670701 from the Academy of Sciences, Czech Republic; by Baxter, Czech Republic.

\section{References}

[1] Miller DT, Ridker PM, Libby P, Kwiatowski DJ. Atheroslerosis - the path from genomics to therapeutics. J Am Coll Cardiol 2007;49:1589-99.

[2] Bijnens AP, Lutgens E, Ayoubi T, Kuiper J, Horrevoets AJ, Daemen MJ. Genome-wide expression studies of atherosclerosis: critical issues in methodology, analysis, interpretation of transcriptomics data. Arterioscler Thromb Vasc Biol 2006;26:1226-35.

[3] Tuomisto TT, Binder BR, Yla-Herttuala S. Genetics, genomics and proteomics in atherosclerosis research. Ann Med 2005;37:323-32.

[4] Májek P, Reicheltova Z, Stikarová J, Suttnar J, Sobotková A, Dyr JE. Proteome changes in platelets activated by arachidonic acid, collagen and thrombin. Proteome Sci 2010;8:56.

[5] Venter JC, Adams MD, Myers EW, et al. The sequence of the human genome. Science 2001;291:1304-51.

[6] Tuñón J, Martín-Ventura JL, Blanco-Colio LM, Lorenzo O, López JA, Egido J. Proteomic strategies in the search of new biomarkers in atherothrombosis. J Am Coll Cardiol 2010;55:2009-16.

[7] De Kleijn, Moll FL, Hellings WE, et al. Local atherosclerotic plaques are a source of prognostic biomarkers for adverse cardiovascular events. Arterioscler Thromb Vasc Biol 2010;30:612-9.

[8] Barderas MG, Tuñón J, Dardé VM, et al. Circulating human monocytes in the acute coronary syndrome express a characteristic proteomic profile. J Proteome Res 2007;6:876-86.

[9] Anderson L. Candidate-based proteomics in the search for biomarkers of cardiovascular disease. J Physiol 2005;563:23-60.

[10] Ping P, Vondriska TM, Creighton CJ, et al. A functional annotation of subproteomes in human plasma. Proteomics 2005;5:3506-19. 
[11] Brea D, Sobrino T, Blanco $M$, et al. Usefulness of haltoglobin and serum amyloid $A$ proteins as biomarkers for atherothrombotic ischemic stroke diagnosis confirmation. Atherosclerosis 2009;205:561-7.

[12] Mateos-Cáceres PJ, García-Méndez A, López Farré A, et al. Proteomic analysis of plasma from patients during an acute coronary syndrome. J Am Coll Cardiol 2004;44:1578-83.

[13] Ikonomidis I, Lekakis J, Revela I, Andreotti F, Nihoyannopoulos P. Increased circulating C-reactive protein and macrophage-colony stimulating factor are complementary predictors of long-term outcome in patients with chronic coronary artery disease. Eur Heart J 2005;26:1618-24.

[14] Foussas SG, Zairis MN, Lyras AG, et al. Early prognostic usefulness of C-reactive protein added to the Thrombolysis In Myocardial Infarction risk score in acute coronary syndromes. Am J Cardiol 2005;96:533-7.

[15] Kosuge $M$, Ebina $T$, Ishikawa $T$, et al. Serum amyloid $A$ is a better predictor of clinical outcomes than C-reactive protein in non-ST-segment elevation acute coronary syndromes. Circ J 2007;71:186-90.
[16] Svensson AM, Whiteley GR, Callas PW, Bovill EG. SELDI-TOF plasma profiles distinguish individuals in a protein C-deficient family with thrombotic episodes occuring before age 40. Thromb Haemost 2006;96:725-30.

[17] Liuzzo G, Biasucci LM, Gallimore JR, et al. The prognostic value of C-reactive protein and serum amyloid a protein in severe unstable angina. N Engl J Med 1994;331:417-24.

[18] Shi Y, Wu Y, Bian C, Zhang W, Yang J, Xu G. Predictive value of plasma fibrinogen levels in patients admitted for acute coronary syndrome. Tex Heart Inst J 2010;37:178-83.

[19] Riedel T, Suttnar J, Brynda E, Houska M, Medved L, Dyr JE. Fibrinopeptides $A$ and $B$ release in the process of surface fibrin formation. Blood 2011;117:1700-6.

[20] Smith JD. Apoliprotein A-1 and its mimetics for the treatment of atherosclerosis. Curr Opin Investig Drugs 2010;11:989-96.

[21] Heinecke JW. The HDL-proteome: a marker and perhaps a mediator of coronary artery disease. J Lipid Res 2009;50(S):167-71.

[22] Tahara N, Yamagishi SI, Tahara A, et al. Serum level of pigment epithelium-derived factor is a marker of atherosclerosis in humus. Atherosclerosis 2011;219:311-5. 